\title{
Analisis Jaringan Komunikasi Koalisi Partai Pemilihan Umum Presiden 2014 dan 2019
}

\author{
Abraham Wahyu Nugroho \\ Program Studi Ilmu Komunikasi Unika Soegijapranata Semarang \\ email: abraham@unika.ac.id \\ Andreas Pandiangan \\ Program Studi Ilmu Komunikasi Unika Soegijapranata Semarang \\ email: pandiangan@unika.ac.id
}

\begin{abstract}
Indonesia is a democracy country with multiparty system. This situation encourages the emergence of party coalitions to be able to compete in political contestation, especially in general elections. This research aims to describe the structure of political party coalitions and the process of forming a coalition by political elites in presidential elections in 2014 and 2019. This research uses data sources from the news clippings of Gatra Magazine, edition March 24 - June 11, 2014 and July 25 - September 5, 2018. The data was analyzed by communication network analysis (CNA) method by using UCINET software. Based on CAN method, the coalition of political parties in the presidential election in 2014 and 2019 is not solid and tend to conflicts, because the political elites prioritize more on the number of relationships than cohesiveness of coalition networks. The other finding is Jokowi becomes popular political actor who has important role to form political party networks in presidential elections in 2014. Susilo Bambang Yudhoyono still has important role in forming political party networks in presidential elections in 2019.
\end{abstract}

Keywords: Political Elites, Political Party Coalition, Communication Networks Analysis

\begin{abstract}
Abstrak
Indonesia merupakan negara demokrasi dengan sistem multipartai. Kondisi demikian mendorong munculnya koalisi partai agar mampu bersaing dalam kontestasi politik khususnya pemilu. Penelitian ini bertujuan untuk menggambarkan struktur jaringan koalisi partai politik yang dibangun dan proses terbentuknya jaringan koalisi partai oleh elit politik pada pemilu presiden 2014 dan 2019. Penelitian ini menggunakan sumber data yang berasal dari kliping berita Majalah Gatra edisi 24 Maret - 11 Juni 2014 dan edisi 25 Juli - 5 September 2018. Kemudian, data dianalisis dengan metode analisis jaringan komunikasi dengan menggunakan software UCINET. Berdasarkan metode analisis jaringan komunikasi, koalisi partai politik peserta pemilu presiden wakil presiden tahun 2014 dan 2019 bersifat tidak solid dan rawan terjadi konflik. Hal ini disebabkan karena elit politik cenderung mengutamakan jumlah relasi yang dibangun daripada kepaduan atau kohesivitas dalam jaringan koalisi. Hasil lainnya menunjukkan bahwa Jokowi merupakan elit politik yang memiliki peran penting dalam terbentuknya koalisi partai terutama pada pilpres 2014 . Sedangkan Susilo Bambang Yudhoyono masih memiliki peran penting dalam terbentuknya koalisi partai politik peserta pilpres 2019.
\end{abstract}

Kata Kunci: Elit Politik, Koalisi Partai Politik, Analisis Jaringan Komunikasi 


\section{PENDAHULUAN}

Indonesia merupakan salah satu negara penganut sistem pemerintahan demokrasi. Meskipun dalam sejarah perjalanannya diwarnai dengan sistem otoriter pada zaman orde baru. Pasca orde baru yang dikenal dengan era reformasi ditandai dengan pemilihan langsung terhadap wakil rakyat, mulai dari anggota dewan perwakilan rakyat, bupati/ walikota, gubernur hingga presiden.

Demokrasi memiliki beberapa kategorisasi. The Economist Intelligence Unit (EIU), salah satu unit bisnis Economist Group yang memiliki fokus tentang riset, mengelompokkan demokrasi menjadi empat, yaitu demokrasi penuh, demokrasi mengambang, rezim hibrid dan otoriter. Setiap tahun EIU merilis laporan tentang kondisi demokrasi setiap negara yang kemudian dikenal dengan indeks demokrasi. EIU sendiri mengelompokkan Indonesia sebagai negara penganut sistem demokrasi mengambang Artinya, demokrasi yang ada di Indonesia belum sepenuhnya disebut demokrasi.

Selain EIU, kategorisasi demokrasi juga dilakukan oleh Arend Lijphart. Hasil penelitian Lijphart terhadap 36 negara menunjukkan bahwa ada dua bentuk demokrasi secara modern, yaitu demokrasi konsensus dan demokrasi mayoritas
(Lijphart, 2012). Contoh negara yang mewakili dua kategori demokrasi ini adalah Amerika Serikat yang mewakili demokrasi kosensus dan Indonesia yang mewakili demokrasi mayoritas.

Dalam sistem demokrasi, peran aktor politik sangat penting sebagai representasi pemerintahan dari, oleh dan untuk rakyat. Peran aktor politik terlihat pada interaksi yang dilakukan dalam rangka mencapai tujuan yaitu mewujudkan kesejahteraan rakyat. Interaksi antaraktor itulah yang kemudian membentuk organisasi berdasarkan kesamaan nilai yang kemudian kita kenal sebagai partai politik. Berdasarkan model demokrasi yang dikemukakan Lijphart, Indonesia merupakan negara demokrasi mayoritas dengan sistem multipartai. Oleh karena itu, koalisi partai diperlukan dalam rangka memenuhi persyaratan dalam kontestasi politik, khususnya pemilihan umum (pemilu) baik legislatif maupun eksekutif.

Sepanjang sejarah pelaksanaan pemilu (1955 - 2019), Indonesia telah menyelenggarakan dua belas kali pemilu, baik secara legislatif (pileg) maupun pemilihan presiden dan wakil presiden (pilpres). Jumlah partai politik yang ikut serta dalam pemilu bersifat dinamis. Mulai dari tiga hingga 172 partai politik peserta pemilu. 
Dinamika partai politik di Indonesia tidak hanya dapat dilihat dari kuantitas partai peserta pemilu, tetapi juga pola relasi di antara partai politik yang ada. Pola relasi yang dimaksud adalah relasi yang tidak pernah permanen dalam membentuk koalisi partai. Sebagai contoh, pada pemilu 2004 dan 2009, PDIP dan Gerindra merupakan dua partai yang berkoalisi. Namun, pada pemilu 2014 dan 2019, kedua partai tersebut beroposisi satu sama lain.

Contoh lain yaitu, koalisi partai di tingkat pusat tidak otomatis diikuti koalisi partai di tingkat daerah (Eriyanto, 2014). Kondisi ini jamak terjadi di berbagai wilayah di Indonesia. Misalnya suatu provinsi atau kabupaten/ kota memiliki koalisi partai PDIP dan dan Demokrat. Namun di tingkat pusat, PDIP dan Demokrat tidak berkoalisi. Di daerah lainnya PDIP berkoalisi dengan Golkar. Sedangkan di provinsi atau kota/ kabupaten lain akan berbeda-beda lagi.

Elit politik yang menjadi representasi dari partai politik di Indonesia memiliki pola relasi yang dapat berubah-ubah dalam setiap periode pemilu. Sikap dan perilaku yang menjadi motivasi membangun relasi merupakan dasar unit analisis politik (Mambo \& Puluhuwula, 2005). Sikap dan perilaku tersebut tampak pada perilaku atau tindakan komunikatif yang dilakukan setiap tokoh atau elit politik. Pola relasi yang sifatnya sementara memiliki implikasi pada pemerintahan yang akan datang maupun sekarang. Kondisi seperti ini juga terjadi pada pemilihan umum presiden (pilpres) 2014 dan 2019.

Pola relasi yang berubah-ubah inilah yang kemudian menjadi dasar dalam merumuskan masalah dalam penelitian ini. Pertama, bagaimana gambaran struktur koalisi partai politik peserta pilpres 2014 dan 2019? Kedua, bagaimana proses terbentuknya jaringan koalisi partai politik pilpres 2014 dan 2019?

\section{METODE PENELITIAN}

Untuk menjawab rumusan masalah yang yang telah ditetapkan, penelitian ini menggunakan metode analisis jaringan komunikasi atau analisis jaringan sosial (Social Network Analysis). Analisis jaringan komunikasi termasuk dalam penelitian kuantitatif. Meskipun masuk kategori penelitian kuantitatif, analisis jaringan komunikasi atau Communication Network Analysis (CNA) memiliki perbedaan dengan penelitian kuantitatif survei. Perbedaan tersebut terletak pada jenis data yang dianalisis. Jika penelitian survei menekankan pada data atribusi (sikap,pengetahuan, perilaku), maka analisis jaringan komunikasi lebih 
menekankan pada data relasional (Eriyanto, 2014). Sebagai contoh, dalam penelitian survei menghasilkan data berapa persen orang yang memilih calon presiden A dan berapa persen yang memilih calon presiden B. Sedangkan dengan menggunakan analisis jaringan komunikasi, maka dapat diketahui mengapa sebagian orang memilih calon presiden A dan sebagian lagi memilih calon presiden $\mathrm{B}$.

Borgatti, dkk. (2013) menjelaskan bahwa konsep jaringan memiliki pengertian fenomena sosial terbentuk dari relasi di antara entitas yang menyusun sistem sosial. Kondisi ini tidak terlepas dari manusia sebagai makhluk sosial. Oleh karena itu, konsep jaringan bersifat fundamental. Jaringan ini muncul dalam berbagai bentuk. Misalnya jaringan pertemanan, jaringan kekerabatan, jaringan bisnis. Studi mengenai posisi aktor dan relasi antar aktor inilah yang kemudian disebut sebagai analisis jaringan sosial.

Metode analisis jaringan komunikasi pada dasarnya mengidentifikasi struktur dan posisi aktor dalam jaringan sosial. Penggunaan metode CNA dalam penelitian ini bertujuan untuk mengetahui struktur koalisi partai politik peserta pemilu dua periode terakhir, yaitu tahun 2014 dan 2019. Selain itu, metode ini juga bertujuan untuk melihat siapa saja yang menjadi aktor-aktor penting dalam membentuk koalisi partai.

Selain jenis penelitian kuantitatif, penelitian ini juga masuk ke dalam kategori riset media. Dokumen pemberitaan media digunakan sebagai sumber data. Hal ini dilakukan karena pertimbangan keterbatasan akses data terhadap elit politik jika dilakukan secara langsung (penelitian lapangan). Pertimbangan lain yaitu, keaktifan media dalam menyampaikan informasi tentang peristiwa yang menunjukkan relasi yang dibangun oleh para elit politik pada masa pemilu. Namun dalam penelitian analisis jaringan, tidak semua berita dapat dijadikan sebagai sumber data. Hanya berita yang memuat aktor dan relasi antar aktor yang dapat dijadikan sebagai sumber data penelitian.

Meskipun masuk dalam kategori penelitian kuantitatif, metode analisis jaringan cenderung menggunakan teknik nonrandom sampling. Hal ini didasarkan pada asumsi bahwa batasan populasi dilihat berdasarkan perspektif aktor. Dalam penelitian analisis jaringan, populasi tidak dapat ditentukan atau dibatasi secara tegas. Karena seorang aktor bisa saja memiliki relasi di luar populasi yang sudah ditentukan. Dalam penelitian ini sampel 
berita yang digunakan yaitu, Majalah Gatra edisi 24 Maret - 11 Juni 2014 dan edisi 25 Juli - 5 September 2018. Dasar pemilihan sampel Majalah Gatra yaitu, berita yang dimuat dalam Majalah Gatra merupakan ringkasan pertemuan atau kontak antara elit partai politik peserta pemilu 2014 dan 2019.

Setelah data terkumpul melalui proses kliping berita tentang koalisi partai, maka selanjutnya dilakukan analisis data. Seperti yang dijelaskan Eriyanto (2014) analisis dilakukan dengan melakukan identifikasi terhadap name generator (semua nama elit politik yang muncul dalam pemberitaan) dan name interpreter (relasi setiap nama elit politik atau aktor yang sudah diidentifikasi). Langkah berikutnya yaitu input data dan analisis dengan menggunakan software UCINET.

Untuk menjawab rumusan masalah atau pertanyaan penelitian, maka disusunlah desain studi dan level analisis. Desain studi dalam penelitian ini lebih memusatkan perhatian pada struktur jaringan utuh (complete networks). Meskipun lebih fokus pada jaringan secara utuh, dalam desain studi dalam penelitian ini juga meliputi jaringan berpusat ego (ego networks). Sedangkan level analisis dalam penelitian memusatkan perhatian pada aktor dan sistem. Secara lebih detail desain studi dan level analisis penelitian ini dapat dilihat pada tabel berikut

Tabel 1

Desain Studi dan Level Analisis

\begin{tabular}{|c|c|c|c|}
\hline \multirow{2}{*}{$\begin{array}{l}\text { Rumusan } \\
\text { Masalah }\end{array}$} & \multicolumn{2}{|c|}{ Desain Studi } & \multirow{2}{*}{$\begin{array}{l}\text { Level } \\
\text { Analisis }\end{array}$} \\
\hline & $\begin{array}{c}\text { Jaringan } \\
\text { Utuh }\end{array}$ & $\begin{array}{c}\text { Jaringan } \\
\text { Ego }\end{array}$ & \\
\hline \multirow{2}{*}{$\begin{array}{l}\text { Bagaimana } \\
\text { gambaran } \\
\text { struktur koalisi } \\
\text { partai politik } \\
\text { peserta pilpres } \\
2014 \text { dan 2019? }\end{array}$} & $\begin{array}{l}\text { Kepadatan } \\
\text { jaringan } \\
\text { utuh }\end{array}$ & $\begin{array}{l}\text { Kepadatan } \\
\text { jaringan } \\
\text { ego }\end{array}$ & Sistem \\
\hline & $\begin{array}{l}\text { Diameter } \\
\text { dan jarak }\end{array}$ & & Sistem \\
\hline \multirow{3}{*}{$\begin{array}{l}\text { Bagaimana } \\
\text { proses } \\
\text { terbentuknya } \\
\text { jaringan koalisi } \\
\text { partai politik } \\
\text { pilpres 2014 } \\
\text { dan 2019? }\end{array}$} & $\begin{array}{l}\text { Sentralitas } \\
\text { tingkatan }\end{array}$ & & Aktor \\
\hline & $\begin{array}{l}\text { Sentralitas } \\
\text { kedekatan }\end{array}$ & & Aktor \\
\hline & $\begin{array}{l}\text { Sentralitas } \\
\text { perantara }\end{array}$ & & Aktor \\
\hline
\end{tabular}

\section{HASIL DAN DISKUSI}

Langkah pertama analisis jaringan komunikasi sebagaimana juga dilakukan dalam penelitian ini adalah penyusunan matriks yang memuat seluruh nama aktor, yaitu tokoh atau elit politik dan relasi di antara elit politik partai peserta pilpres 2014 dan 2019. Berdasarkan matriks yang telah disusun, maka ditemukan sebanyak 28 aktor yang terlibat dalam proses pembentukan koalisi partai politik pada tahun 2019 dan 50 aktor yang terlibat dalam pembentukan koalisi partai tahun 2014. Setelah matriks selesai disusun, maka langkah berikutnya adalah menjawab 
rumusan masalah berdasarkan desain studi dan level analisis yang sudah ditentukan.

\section{Gambaran Struktur Koalisi Partai}

Struktur koalisi partai merupakan gambaran jaringan yang terbentuk dalam koalisi partai politik peserta pilpres 2014 dan 2019. Struktur ini mencakup semua aktor dan relasi yang terjadi di antara para aktor yang terlihat pada sosiogram berikut ini

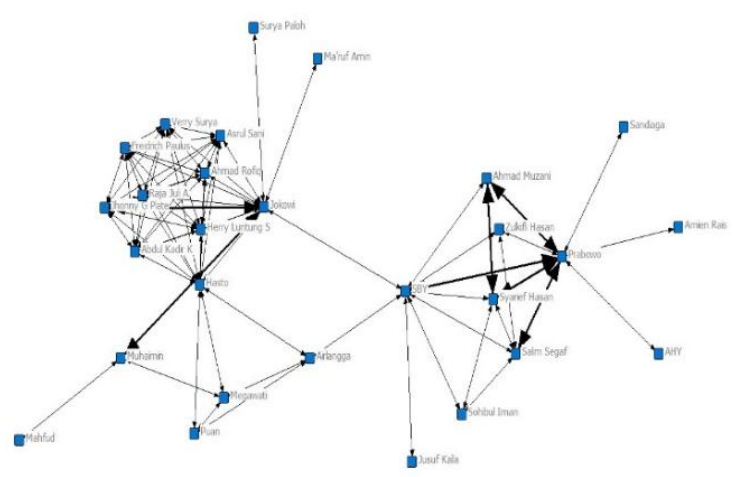

Gambar 1

Struktur Jaringan Utuh Koalisi Partai Pilpres 2019

Sumber: Data Olahan

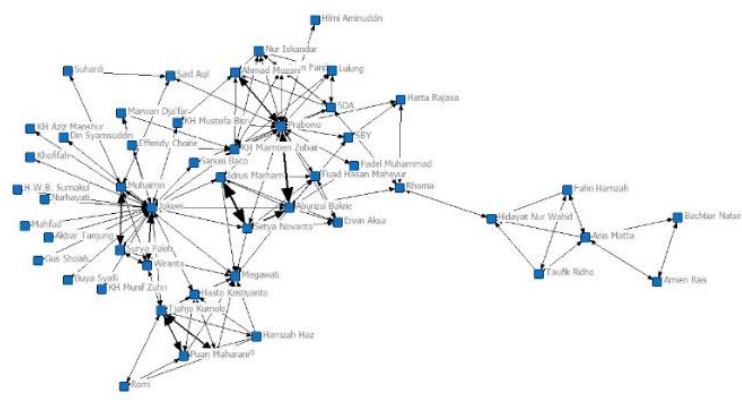

Gambar 2

Struktur Jaringan Utuh Koalisi Partai Pilpres 2014

Sumber: Data Olahan
Gambaran atau deskripsi mengenai struktur jaringan koalisi partai pilpres 2014 dan 2019 dapat dipahami melalui tiga parameter. Pertama, kepadatan jaringan utuh. Parameter ini untuk menggambarkan intensitas interaksi yang terjadi antar aktor politik. Kedua, diameter dan jarak. Parameter ini memberikan informasi tentang jarak terjauh dan jarak rata-rata setiap aktor untuk dapat terhubung satu sama lain. Ketiga, kepadatan jaringan ego. Parameter yang ketiga ini menunjukkan kohesivitas atau kekuatan hubungan yang terjadi antar aktor dalam jaringan.

Tabel 2

Hasil Perhitungan Parameter Struktur Jaringan Koalisi Partai Pilpres 2014 dan 2019

\begin{tabular}{|c|l|c|c|}
\hline $\begin{array}{c}\text { Desain } \\
\text { Studi }\end{array}$ & Parameter & $\begin{array}{c}\text { Nilai } \\
(2019)\end{array}$ & $\begin{array}{c}\text { Nilai } \\
(2014)\end{array}$ \\
\hline $\begin{array}{c}\text { Jaringan } \\
\text { Utuh }\end{array}$ & $\begin{array}{l}\text { Kepadatan } \\
\text { (density) }\end{array}$ & 0,202 & 0,083 \\
\hline & Diameter & 5 & 7 \\
\hline $\begin{array}{c}\text { Jarak rata- } \\
\text { rata }\end{array}$ & 2,431 & 2,785 \\
\hline Ego & $\begin{array}{c}\text { Kepadatan } \\
\text { (density) }\end{array}$ & $\begin{array}{c}0,46 \\
\text { (Jokowi) }\end{array}$ & $\begin{array}{c}0,04 \\
\text { (Jokowi) }\end{array}$ \\
\hline & \multicolumn{2}{|c|}{$\begin{array}{c}0,25 \\
\text { (Prabowo) }\end{array}$} & $\begin{array}{c}\text { (Prabowo) } \\
\text { (Pringan }\end{array}$ \\
\hline
\end{tabular}

Berdasarkan tabel di atas, temuan terkait gambaran struktur koalisi partai peserta pilpres dapat diuraikan sebagai berikut. Pertama, baik koalisi partai yang terbangun pada pilpres 2014 dan 2019 bersifat 
longgar atau memiliki kepadatan yang rendah, yaitu 0,2 (tahun 2019) dan 0,08 (tahun 2014). Angka kepadatan jaringan berkisar antara 0 hingga 1. Semakin mendekati angka 0 artinya kepadatannya rendah, dan sebaliknya. Kondisi ini dapat dimaknai bahwa setiap elit politik atau aktor politik tidak berinteraksi dengan semua aktor dalam jaringan.

Kedua, jarak rata-rata. Data ini menggambarkan rata-rata langkah yang diperlukan oleh semua aktor agar bisa saling berinteraksi satu sama lain. Temuan nilai jarak rata-rata 2,4 (tahun 2019) dan 2,8 (tahun 2014) menunjukkan angka yang besar untuk jumlah aktor 28 (tahun 2019) dan 50 (tahun 2014). Angka yang besar menunjukkan bahwa jaringan koalisi yang dibangun relatif longgar.

Ketiga, diameter. Data ini menunjukkan berapa jarak terjauh dari setiap aktor untuk bisa terhubung satu sama lain. Hasil perhitungan dengan menggunakan UCINET menunjukkan bahwa diameter jaringan koalisi partai tahun 2019 sebesar 5 dan tahun 2014 sebesar 7. Artinya jarak paling jauh seorang aktor melakukan kontak aktor lain dalam jaringan yaitu 5 langkah (2019) dan 7 langkah (2014). Angka ini juga semakin menegaskan bahwa jaringan koalisi yang dibangun bersifat relatif longgar.
Konsep kepadatan, jarak dan diameter jaringan digunakan untuk melihat kohesivitas atau kekompakan aktor dalam jaringan. Jaringan yang padat atau kohesif artinya jaringan yang di dalamnya terdapat hubungan yang kuat antar anggota. Hal ini ditandai dengan semua anggota memiliki relasi dengan semua anggota. Sedangkan temuan hasil penelitian ini menunjukkan bahwa baik koalisi partai politik yang dibangun pada pilpres 2014 dan 2019 yaitu sama-sama rendah.

Kondisi jaringan dengan kohesivitas rendah ini dapat dimaknai bahwa elit politik di Indonesia lebih mengutamakan jumlah relasi yang sebanyak mungkin dengan elit politik lain daripada memikirkan kekompakan antar anggota dalam jaringan yang sama. Tujuan dari membangun relasi sebanyak mungkin bisa diasumsikan bahwa relasi yang banyak dapat memberikan banyak pilihan dalam membangun kerja sama. Sehingga seorang aktor akan memiliki keleluasaan dalam memilih kerja sama yang dianggap paling menguntungkan. Namun, konsekuensinya adalah jaringan koalisi yang terbentuk tidak kompak.

Temuan lain yang mendukung kondisi jaringan koalisi partai pemilu di Indonesia tidak kompak atau tidak solid adalah kepadatan jaringan ego yang rendah. 
Dalam dua periode terakhir pilpres, terdapat dua koalisi partai dengan dua aktor utama, yaitu Jokowi dan Prabowo. Berdasarkan perhitungan kepadatan jaringan ego, baik Jokowi maupun Prabowo memiliki angka yang rendah. Hal ini menunjukkan bahwa jaringan koalisi yang dibangun bersifat terbuka. Artinya tidak banyak aktor yang saling berinteraksi membangun relasi satu sama lain. Misalnya, Jokowi menjalin relasi dengan Akbar Tanjung, lalu bertemu dengan Surya Paloh dan Setya Novanto. Namun, Akbar Tanjung tidak pernah bertemu dengan Surya Paloh atau Setya Novanto. Demikian pula Surya Paloh yang tidak bertemu dengan Setya Novanto.

Implikasi dari temuan data mengenai struktur jaringan koalisi partai peserta pilpres di Indonesia tahun 2014 dan 2019 adalah keberlanjutan koalisi partai. Idealnya, koalisi partai dibangun atas dasar ideologi, kesamaan program dan juga kekompakan antar anggota dalam koalisi atau jaringan. Sehingga koalisi partai dapat berlangsung dalam jangka waktu yang lama atau bahkan permanen. Namun kondisi seperti ini tidak tampak pada jaringan koalisi partai pilpres di Indonesia. Artinya, koalisi ini mudah pecah dan rawan terjadi konflik.
Karakteristik lain dari jaringan koalisi partai politik peserta pilpres di Indonesia adalah terbentuknya jaringan tersebut cenderung mendekati batas akhir pendaftaran di Komisi Pemilihan Umum (KPU). Alasannya yaitu masing-masing aktor politik saling melakukan perhitungan mana koalisi yang dianggap paling menguntungkan berdasarkan jumlah relasi yang sudah dibangun dengan aktor lain. Kondisi seperti ini akan memunculkan pemerintahan yang cenderung tidak stabil. Karena pemerintahan yang dihasilkan dari koalisi semacam ini akan diwarnai perbedaan pendapat antar anggota dalam koalisi yang sama. Bahkan seolah-olah ada anggota partai koalisi yang bertindak seperti partai oposisi.

\section{Proses Terbentuknya Jaringan Koalisi}

\section{Partai}

Terbentuknya koalisi partai politik pilpres tidak bisa terlepas dari interaksi yang dilakukan elit politik di Indonesia. Proses pembentukan ini dapat diuraikan melalui analisis terhadap tiga parameter, yaitu sentralitas tingkatan, sentralitas kedekatan dan sentralitas keperantaraan para aktor politik.

1. Sentralitas Tingkatan

Parameter sentralitas tingkatan digunakan untuk menentukan tingkat 
popularitas aktor. Berkaitan dengan hal tersebut terdapat dua macam posisi aktor terkait dengan tingkat popularitasnya. Pertama yaitu aktor yang paling sering dihubungi (indegree). Posisi ini menunjukkan bahwa aktor tersebut dianggap memiliki kekuatan. Kedua, aktor yang paling sering menghubungi (outdegree). Aktor dalam posisi outdegree dianggap memiliki posisi yang kurang menguntungkan. Tabel berikut menunjukkan tiga aktor dengan tingkat (indegree) paling tinggi pada pilpress 2014 dan 2019.

Tabel 3

Tiga Aktor Terpopuler Pada Pilpres 2014 dan 2019

\begin{tabular}{|l|l|c|l|c|}
\hline \multirow{2}{*}{ No } & \multirow{3}{*}{ Aktor } & $\begin{array}{c}\text { Pilpres } \\
2019\end{array}$ & \multirow{2}{*}{ Aktor } & 2014 \\
& & InDeg & & InDeg \\
\hline 1 & Jokowi & 14.000 & Jokowi & 24.000 \\
\hline 2 & Prabowo & 12.000 & Prabowo & 19.000 \\
\hline 3 & SBY & 10.000 & Megawati & 10.000 \\
\hline
\end{tabular}

Sumber: Data Olahan

Berdasarkan tabel di atas, Jokowi menjadi aktor dengan tingkat popularitas tertinggi, baik pada pilpres 2014 maupun 2019 . Meskipun Jokowi dianggap memiliki popularitas, tetapi cenderung untuk mengambil inisiatif dalam menghubungi atau menjalin relasi dengan aktor politik lainnya. Hal ini juga terlihat dari outdegree Jokowi.
2. Sentralitas Kedekatan Aktor

Parameter sentralitas kedekatan aktor digunakan untuk melihat seberapa dekat seorang aktor politik dapat menghubungi aktor lain dalam jaringan yang sama. Secara sederhana sentralitas ini menunjukan tingkat kedekatan antar elit politik dalam jaringan. Konsep kedekatan ini memiliki pemahaman berbeda dengan popularitas. Jika popularitas menyangkut seberapa banyak seorang aktor dihubungi oleh aktor lain, maka kedekatan menunjukkan seberapa dekat relasi yang dibangun oleh aktor. Artinya, aktor yang populer belum tentu memiliki tingkat kedekatan yang tinggi, demikian juga sebaliknya.

Sentralitas kedekatan juga memiliki dua jenis, yaitu outcloseness (kedekatan yang diukur berdasarkan aktor yang menghubungi aktor lain) dan incloseness (kedekatan yang diukur berdasarkan aktor yang dihubungi aktor lain).Berdasarkan dua jenis kedekatan tersebut, yang lebih penting adalah outcloseness. Nilai sentralitas kedekatan berbanding terbalik dengan tingkat keeratan relasi. Semakin rendah nilai sentralitas kedekatan, maka semakin erat hubungan atau relasi di antara aktor. 
Tabel berikut menunjukkan tiga orang dengan sentralitas kedekatan aktor tertinggi pada pilpres 2014 dan 2019

Tabel 4

Tiga Aktor Dengan Sentralitas Kedekatan Tertinggi Pada Pilpres 2014 dan 2019

\begin{tabular}{|l|l|l|l|l|}
\hline \multirow{2}{*}{ No } & \multirow{3}{*}{ Aktor } & $\begin{array}{c}\text { Pilpres } \\
2019\end{array}$ & \multirow{2}{*}{ Aktor } & $\begin{array}{c}\text { Pilpres } \\
2014\end{array}$ \\
\cline { 3 - 4 } & & OutClose & & OutClose \\
\hline 1 & Jokowi & 44.000 & Jokowi & 111.000 \\
\hline 2 & SBY & 46.000 & ARB & 123.000 \\
\hline 3 & Airlangga & 56.000 & $\begin{array}{l}\text { Setya } \\
\text { Novanto }\end{array}$ & 127.000 \\
& & & \multicolumn{3}{|c|}{ Sumber } \\
\hline
\end{tabular}

Berdasarkan tabel di atas, menunjukkan bahwa Jokowi memiliki tingkat kedekatan yang paling tinggi di antara aktor-aktor politik yang lain. Artinya, selain popularitas yang tinggi, Jokowi juga merupakan aktor politik yang dapat diterima oleh aktor-aktor politik yang lain.

3. Sentralitas Perantara

Parameter ketiga ini menggambarkan siapa aktor yang paling penting dalam jaringan. Alasannya adalah aktor yang memiliki nilai sentralitas perantara yang tinggi berperan penting dalam menghubungkan satu aktor dengan aktor lain. Aktor ini dianggap sebagai perekat di mana tanpa kehadirannya sangat dimungkinkan jaringan bisa terpecah. Tabel berikut ini menunjukkan tiga orang aktor yang memiliki nilai sentralitas perantara tertinggi jaringan koalisi partai pada pilpres 2014 dan 2019.

Tabel 5

Tiga Aktor Dengan Sentralitas Perantara

Tertinggi Pada Pilpres 2014 dan 2019

\begin{tabular}{|l|l|l|l|c|}
\hline No & Aktor & $\begin{array}{c}\text { Pilpres } \\
2019\end{array}$ & Aktor & $\begin{array}{c}\text { Pilpres } \\
2014\end{array}$ \\
\hline 1 & SBY & 369.800 & $\begin{array}{l}\text { Joko } \\
\text { wi }\end{array}$ & 1.374 .277 \\
\hline 2 & Jokowi & 360.500 & ARB & 428.339 \\
\hline 3 & Prabowo & 152.333 & $\begin{array}{l}\text { Prabo } \\
\text { wo }\end{array}$ & 395.730 \\
\hline
\end{tabular}

Tabel di atas menunjukkan dua orang elit politik yang memiliki peran penting dalam menghubungkan satu aktor dengan aktor lainnya, yaitu Joko Widodo (Jokowi) pada pilpres 2014 dan Susilo Bambang Yudhoyono (SBY) pada pilpres 2019.

\section{KESIMPULAN DAN SARAN}

Deskripsi atau gambaran mengenai struktur jaringan koalisi partai yang dibangun pada masa pemilihan umum presiden (pilpres) 2014 dan 2019 di Indonesia menunjukkan bahwa koalisi partai tidaklah kompak dan rawan terjadi konflik. Hal ini disebabkan karena elit politik lebih mengutamakan jumlah relasi sebanyak mungkin daripada membangun relasi yang solid. Kondisi seperti ini bisa berpotensi menimbulkan ketidakstabilan pemerintahan pada masa yang akan datang. 
Proses terbentuknya koalisi partai politik tidak bisa terlepas dari peran para elit politik. Pada pilpres periode 2014, Jokowi menjadi elit politik yang berperan penting dalam membentuk koalisi partai, karena dianggap sebagai aktor yang paling populer dan dapat diterima oleh banyak elit politik yang lain. Sedangkan pada pilpres 2019, SBY masih menjadi aktor penting dalan menghubungkan antarelit politik. Tidaklah mengherankan jika Partai Demokrat terkesan tidak terlalu kuatir jika tidak memiliki koalisi partai, sehingga cenderung bersikap netral.

Penelitian ini memiliki keterbatasan dalam menyimpulkan deskripsi dan terbentuknya koalisi partai politik peserta pilpres 2014 dan 2019. Alasannya adalah data penelitian ini bersumber pada liputan media yang sangat tergantung pada priming dan framing berita terkait relasi yang terjadi di antara elit politik di Indonesia pada masa pemilihan umum presiden dan wakil presiden. Oleh karena itu penelitian berikutnya disarankan untuk melakukan analisis jaringan berdasarkan data lapangan atau media selain Majalah Gatra.

\section{DAFTAR PUSTAKA}

Borgatti, Stephen P, Martin G Everett, and Jeffrey C Johnson. (2013). Analyzing
Social Network. Los Angeles: SAGE Publications Ltd.

Nugroho, Heru. (2012). Demokrasi dan Demokratisasi: Sebuah Kerangka Konseptual untuk Memahami Dinamika Sosial-Politik di Indonesia. Jurnal Pemikiran Sosiologi, 1(1), 114.

Eriyanto. (2014). Analisis Jaringan Komunikasi: Strategi Baru dalam Penelitian Ilmu Komunikasi dan Ilmu Sosial Lainnya. Jakarta: Kencana Prenada.

Hakim, Rakhmat Nur (4 Oktober 2018) Partai Politik yang Bertarung di Pemilu dari Masa ke Masa. Kompas.com diakses dari https://nasional.kompas.com/read/20 18/02/20/13275281/partai-politikyang-bertarung-di-pemilu-dari-masake-masa

Lijphart, Arend. (2012). Patterns of Democracy: Government Forms and Performance in Thirty-Six Countries. $\left(2^{\text {nd }}\right.$ ed.). New Haven: Yale University Press.

McNair, Brian. (2011). An Introduction to Political Communication. (5 $5^{\text {th }}$ ed.). London: Routledge.

Rawnsley, Gary D. (2005). Political Communication and Democracy. New York: Palgrave Macmillan.

The Economist Intelligence Unit's

Democracy Index (5 Juni 2019) diakses dari https://infographics.economist.com/2 018/DemocracyIndex/ 